\title{
455. $T_{1}$ 強調画像で高信号を示す腫瘤の化学シフトを用いた検討
}

The study of high intensity tumor in $\mathrm{T}_{1}$ WI using chemicalshift

神户市立中央市民病院 放射線科

○奥町 英世 屾下順一俊之

(Hideyo Okumachi) (Junichi Yamashita) (Toshiyuki Taguchi)

高島一民半崎 正隆 関 直秀

(Hitomi Takashima) (Hasataka Hanzaki). (Naohide Seki)

（目的） MR画像において、并般的に病変部は $\mathrm{T}_{1}, \mathrm{~T}_{2}$ 共に延長した像、すなわち $\mathrm{T}$ 強調画像 で低信号、 $\mathrm{T}_{2}$ 強調画像で高信号として描出される。しかしながら、 $\mathrm{T}_{1}$ 強調画像においても高信号を 示す腫瘤性病変が少なからず存在する。今回、T、強調画像で高信号を示す腫瘤の内容が化学シフト を利用することにより簡単に推測できるものと考え検討した。

（方 法） 油脂ファントムが、 $\mathrm{T}$ 強調画像で高信号となることを 確認した後、Gradient Echo法（F L A S H）でTEを 10 msecから

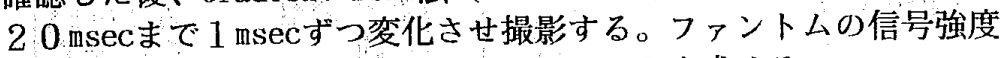
変化からIn-phase、out-of-phaseとなる T Eを求める。

臨床応用として、肝疾患に用いた。

装置は MAGNETOH H 15 （1．5 テスラ超伝導型）を使用した。

（結 果） 皮下脂肪はオリーブ油と同じ傾向を示したが、油脂の 種類により化学シフトが少し異なった。人体ではIn-phaseは T E が $14 \mathrm{msec}, 18 \mathrm{msec} 、$ Out-of-phaseはT Eが $12 \mathrm{msec}, 16 \mathrm{msec}$ で得られた。純粋な油は割合早く減衰するが、Gd-DTPA溶液C $0.1 \mathrm{mmol} / \mathrm{kg})$ は長いT E まで常に高信号であった。 油脂成分が $10 \%$ 以下になると検出が難しくなった。正常な肝実質は化学 シフトの影響は認められないが、脂肪肝はよく検出できた。

(考、察) ルーチン撮影に、TEが $12 、 14 、 16 、 18 \mathrm{msec} の$ うち、いずれか 3 回の息止めスキャンを追加することで $\mathrm{T} 1$ 強調 画像で高信号を示す腫瘤性病変が脂肪沈着によるものか、出血に よるもの等、簡単に推測でき、肝癌における特徴的所見の脂肪 変性の同定に有効と考えら机る。
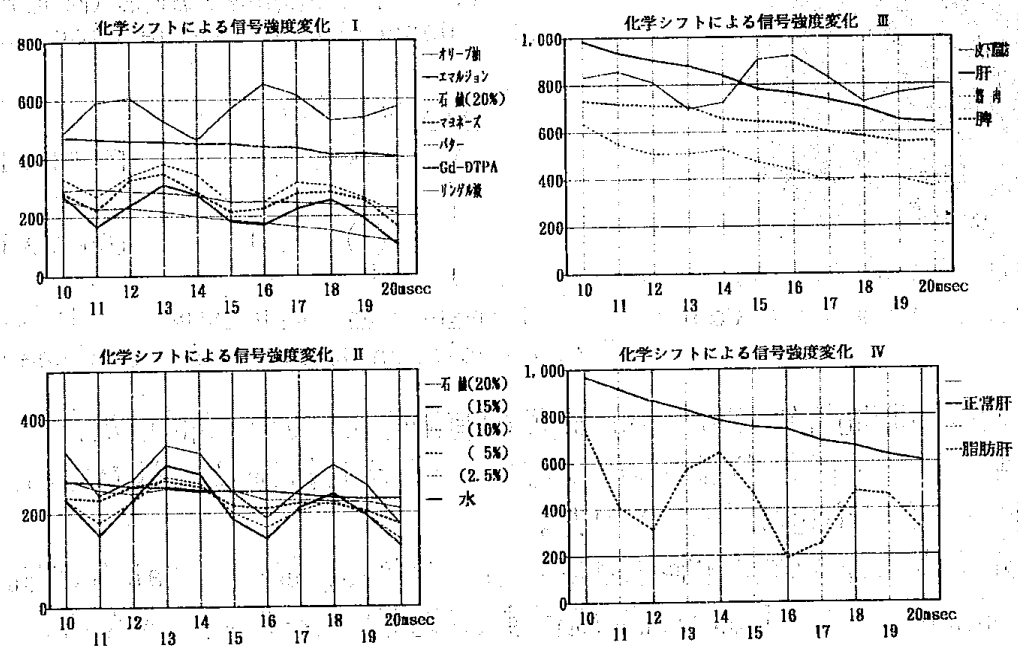

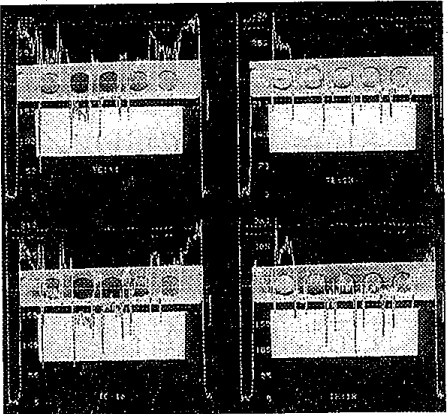

out of Phase: In Phase

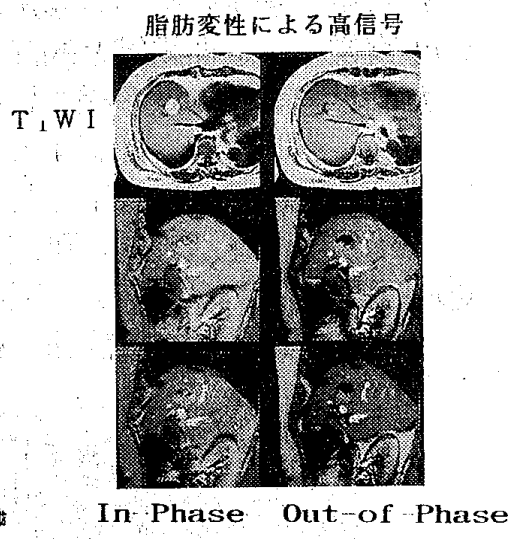

出血による禹信号

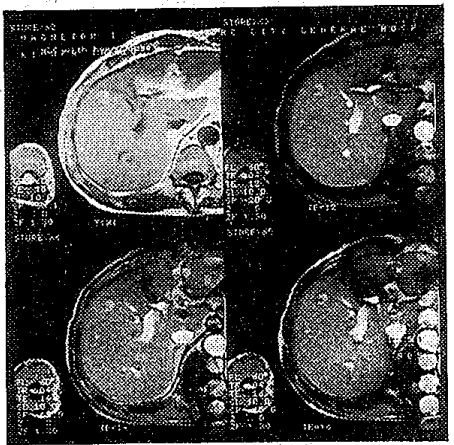

In Phase Out-of-Phase 